\title{
Problems of Overcoming Poverty in the Republic of Kazakhstan
}

\author{
Zhanna A. Khamzina \\ Yermek A. Buribayev \\ Zhambyl K. Oryntayev
}

Kazakh National Pedagogical University named after Abay, Republic of Kazakhstan

Anarkhan Kuttygalieva

West Kazakhstan Engineering Humanities University, Republic of Kazakhstan Email: ermek_a@rambler.ru

\section{Doi:10.5901/mjss.2015.v6n3s5p169}

\section{Abstract}

\begin{abstract}
Events of the later stage of development that have taken place on a global scale of the crisis of financial and economic nature were destined to affect the Republic of Kazakhstan as an integrated member of the international community. However, the negative consequences in the form of a substantial reduction of the state budget did not result in reduction of the state social obligations. Refinement of the methodology for determining the subsistence level, the implementation of its calculation based on zoning of the country on the living conditions of the population are the urgent issues for Kazakhstan. Recalculation of the "consumer basket" has to be based on the actual needs of the population, while the law has to guarantee the minimum wage to be brought to a higher social standard, and define the poverty line by the level of the subsistence minimum. The concept being applied for calculation of the poverty line is not enough objective, as it considers poverty as incomes below the subsistence minimum. Poverty rate in Kazakhstan is still at a very high level, which will continue to rise due to the economic crisis. There is a considerable proportion of ineffective employment. About one-third of self-employed people today are engaged in unproductive and illegal labor, not being covered by social security and being at the edge of poverty. Labor market shows unemployment and unfilled vacancies both at once. Poverty persists. Authors suggest to consider the concept of social modernization as dealing with the problem of poverty reduction, being a priority objective of national development in the context of the strategic plan for the development of Kazakhstan until 2050.
\end{abstract}

Keywords: social security, poverty, subsistence minimum, food basket, poor, social welfare

\section{Introduction}

Since gaining independence, the Republic of Kazakhstan adopted a policy of progressive construction of the social state. During the construction of market relations, in the years of sustained economic growth, and during current financial and economic global crisis, the social priorities have always remained indisputable for state authorities. Kazakhstan undergoes a number of serious reforms in the social sphere. Government has developed a concept of social modernization for the period up to 2020. Implementation of this document has to change the system of social protection, education, health - all areas of life in the country. By the end of 2014, per capita GDP amounted to almost 13 thous. USD, being 72 times higher in comparison with 1991. The number of people with incomes below the subsistence level, compared with 1998, has decreased by 12.5 times, the average monthly wage increased by 11.2 times, the unemployment rate fell to $5.2 \%$. The minimum amount of pension payments in 1998 amounted to 2,440 tenge, while today it is 11 times higher $-28,396$ tenge or 154 USD. The average pension increased by 10.5 times (note: given data on the growth of social indicators excluding inflation). Thus, even in a difficult economic and financial situation, the state adheres to its primary values as of the social state, with the social sphere being the most important factor determining the effectiveness of state authority, able to perform its social obligations in any case.

Arguments that determine the timeliness of this work are: lack of legal security of social public relations aimed at providing social benefits to the population living below the poverty line; limitations of theoretical, methodological, and conceptual justification of the essence, content, structure of standards used for the provision of social assistance to the poor; certain disunity of the state policy on social support of the poor. The research topic has been previously studied in 
fragments, and has still not been a subject of comprehensive monographic study. The scientific sources reflect the results of the analysis of only some of the legal provision of state social protection measures upon the occurrence of such a social fact, as the gaining of income below the poverty level.

However, scientists are always interested in the problems of poverty reduction, not only as an independent scientific discipline, but in relation to the general theoretical, constitutional and legal issues determining the nature of the social state, the system of constitutional social rights and guarantees of their implementation, execution of the social functions by the state in relation to the social interests, of the state social policy, of the framework of governance and other legal phenomena. Problems of living standards and poverty are covered in detail in the works of Atkinson (2004), Clark and Hulme (2005), Clark (2005), Schumpeter (2011), Maleva and Ovcharova (2010), Razumov and Yagodkina (2007), Sen (2004), Townsend (1988) and others. Yet the issues of legal support to overcome poverty in the Republic of Kazakhstan were not subject to independent research. The very formulation of the problem in the proposed perspective, studying it through legal mechanisms, has not been the subject of scientific analysis to date.

The aim of this study is the analysis of problems and methods for overcoming poverty in the Republic of Kazakhstan by studying its legal obligations of social protection of the population, and the complex methods used to calculate the poverty line in the country. Authors set out the following research tasks. To the study the international standards of social protection guarantees of the poor, the peculiarities of the social system of social protection at the level of income equial to the poverty line and the subsistence level, the analysis and elaboration of solutions to problems of legal support to increase the efficiency of public administration in the fight against poverty.

\section{Challenges and Prospects of Poverty Reduction in the Republic of Kazakhstan}

Problems of poverty reduction in the Republic of Kazakhstan are studied to some extent. The legal aspect is reflected in the legal industry analyzes on governance issues of social protection of the population, labor law, international standards of social and labor rights. All studies indicate imperfect methodology for determining the major social indicators. Since 2006, began the process of gradual transition in the accrual of social payments from the meaningless monthly payments index to the subsistence minimum. From this period on, the Law on the republican budget for the respective calendar year a fixed minimum subsistence level was introduced for the calculation of the size of the basic social benefits. The foregoing are significantly late measures in the implementation of the Law of the Republic of Kazakhstan (RK) "On subsistence minimum", adopted on 16 November 1999. That is, since the adoption of the law and to the period of implementation of its provisions took approximately seven years.

Article 3 of the Law determines the functions of a living wage:

- assessment of the quality of life and the definition of the poverty line;

- determination of the areas of social policy and the implementation of measures of social support of the population;

- justification of the minimum monthly wage, minimum pension and basic social benefits.

The latter of the above areas of application of the subsistence level for determining the value of basic social payments has just begun to be applied by the legislator and the public authorities on the approximation of the laws. We believe that the work in this direction can be complicated by a lack of social legislation in determining the definition of "basic social benefits" to the minimum amount of which the cost of living should be justified, which in turn, might lead to an unjustified delay in the process of bringing social payments in line with the social standards. That is the cost of living should be taken as a basis for determining the payments, because socially it is the main source of living to the recipients, which must comply with generally accepted standards of living.

It seems that in this respect the basic social benefits should be treated as payment, provision of which is guaranteed by the state, both at the expense of the republican and local budgets and other sources of funding. Authors argue, that these payments should be classified as insurance payments from the State Social Insurance Fund, since the occurrence of such social facts as disability, loss of breadwinner, and loss of employment, the social insurance payments are the main sources of livelihood. By similar reasoning, benefits for families with children assigned to care for the child, as well as in cases when the average family income falls below the food basket, payments should be appointed in proportion to the cost of living. Moreover, authors suggest to consider the revision of the principles of nomination of payments in accordance with established standards should be implemented with respect to the state special benefits to persons who worked in underground and open cast mining, in jobs with hazardous and difficult conditions, as it causes disability of these persons before retirement age. The subsistence level has to determine the amount of payment of temporary disability benefits by the employer, taking into account the lost earnings.

Special state benefits should also be calculated according to the subsistence level and be recognized as the 
source of livelihood for many groups of recipients. Counterarguments in this aspect can be reduced to the proposition that these allowances were introduced in the social security system to compensate for the abolition of the natural benefits, while performing a compensatory role. They emphasize the special social status of its beneficiaries such as persons with disabilities, members and persons with disabilities after the Great Patriotic War, and the persons under the equivalent status, families of deceased servicemen on duty, the victims of mass political repressions, persons who had special services to the state, and many others. That is, these benefits originally performed the role of substitute for the natural loss of benefits and could not be the main source of existence. Objection is that, as an additional form of social security benefits these benefits may be conditionality considered solely for people with disabilities on various grounds. For all other categories, there are more than ten, these benefits usually are the main sources of livelihood.

Assistance to poor is generally decentralized in Kazakhstan, which is expressed in the introduction in 2001 of national targeted social assistance to the national social security system. It has become a form of financial support for people (families) with the lowest income, funded by the local budgets, appointed by the local executive bodies after a full examination of all aspects of the quality of life of the applicants, but guaranteed by a centralized regulatory legal act - the RK Law of July 17, 2001 № 246-II "On state targeted social assistance". Targeted social assistance is a payment in cash provided by the State to individuals (families) with a monthly per capita income below the poverty line established in the regions, the cities of Astana and Almaty. Social assistance is a means of combating poverty by raising incomes, to a living wage. A living wage (i.e. subsistence minimum) is the required minimum cash income per person equal in magnitude to the minimum consumer basket, which in turn includes the cost of the food basket and the cost of non-food goods and services. The poverty line is determined on a quarterly basis at a rate of 40 per cent of the cost of the minimum necessary non-food products and services of the subsistence minimum. The right to the targeted social assistance is granted to citizens of the republic, repatriates, persons with refugee status, foreigners and stateless persons who have residence permits and permanent residence in the Republic of Kazakhstan, with a per capita income that does not exceed the poverty line.

According to the Ministry of Health and Social Development of the RK, in 2014 13,186 families (56,1 thous. pers.) whose income does not exceed the poverty line, have received grants in the amount of 1.3 billion. tenge. According to official statistics at the beginning of 2015, the share of children among the persons who are appointed to social assistance is more than 64.7 per cent, that is, the vast majority of beneficiaries are children living below the poverty line. On January $12015,562.6$ thous. children in the RK have an income below the food basket. The total population of the RK as of February 12015 was 17,439,271 people, including minors constitute 5,634,503 child, i.e. every $10^{\text {th }}$ child in Kazakhstan is not provided by the income that would allow to purchase a monthly food basket. We believe that the presented data evidently shows the need for further improvement of measures to eradicate poverty.

The category of "poverty" in Kazakhstan is associated with the concept of "living wage", the ratio of the real income of a person or family with the cost of living can be attributed to a person classified as poor. The authorized body on statistics and the authorized state body for social protection of the population calculate the subsistence minimum based on the cost of the minimum food basket, increased by a fixed share of the costs to the minimum necessary non-food goods and services.

The subsistence minimum is intended for the annual:

- Assessment of the standard of living and to determine the poverty line;

- Determine the areas of social policy and the implementation of measures of social support of the population;

- Justification for a minimum monthly wage, minimum pension and basic social benefits.

Thus, the cost of living is the most important basic guideline for the execution of the state social obligations to society, the fight against poverty, guarantees of the decent pay to employees. In this regard, an adequate definition of meaningful human needs and therefore money "filling" of the living wage should be the most important task for the public authorities in conducting social policies, processes of its legal security. Naturally, the cost of living depends primarily on the economic, social and cultural development of the state, its historical background.

As the number one issue of the $1990-2015$ period, is to halve the proportion of people whose income is less than one dollar a day, being defined by the goals of the UNPO program on Millennium Development in Kazakhstan. It is noted that although the 1 USD per day is an international standard for measuring poverty, most countries define their own poverty line. In Kazakhstan, the two measurement indicators are as follows: a living wage (equal to the minimum consumer basket) and the poverty line, which is an average of $40 \%$ of the subsistence minimum. The data show that the proportion of poor people in Kazakhstan fell significantly over the past few years. However, the presence of disparities between urban and rural areas, as well as between different areas of the country is disturbing.

As a second objective of this policy document is defined to half the proportion of people who suffer from hunger in the 1990 - 2015 period. It is noted that Kazakhstan has no direct signs of hunger, but there is a high level of micronutrient 
deficiencies. Therefore, this problem has been reformulated for the country as follows: to halve the number of people who are not receiving a balanced diet. Malnutrition (or unbalanced diet) reduces energy and mental activity and may represent a serious risk to human health, and in the most severe cases, is an existential threat.

One of the major directions of the decision set out in the Report on the implementation of the global development goals of the Millennium Declaration, which was signed at the UN Summit in September 2000, is to increase the living wage and the level of poverty in Kazakhstan in accordance with recognized standards. This course of action, in our view, should include:

- Expansion of the list of parameters that make up the food basket, in accordance with generally accepted standards of human nutrition, in conformity with the requirements of a balanced diet in Kazakhstan. "The basis of subsistence minimum is the food basket that contains the value of science-based diet. If we compare this figure with the CIS countries, where it is $2100-2500 \mathrm{kcal}$ per person per day, and in the US, where the figure is much higher $-3700 \mathrm{kcal}$, it is possible to establish the difference in the standard of living of the population in these countries" (Babaev, 2009, p. 20).

- Elaboration of the value in terms of cost of non-food goods and services on the basis of scientific evidence and legislative support, which together constitute the food basket in volume and value terms, the cost of living. In modern conditions of Kazakhstan, the non-food costs are determined arbitrarily, not scientifically justified and do not meet the objectives and their use in the subsistence minimum. According to the Rules for calculating the subsistence minimum adopted in Kazakhstan, the cost of the food basket is calculated by the authorized state body for statistics by multiplying the scientifically-based physiological norms of consumption of foods included in the food basket for the various age groups, on average prices registered in representative sites and retail outlets as of the middle of this month in the city of republican status, capital, provincial and district centers. The share of the food basket is $60 \%$ of the subsistence minimum.

- Thus, the cost of non-food goods and services accounts for $40 \%$ of the subsistence minimum. Hence, the nonfood part is neither practically by the legislator or scientifically justified, being calculated on the basis of the value of the food basket, which has nothing to do with non-food goods and services. This legal situation requires a resolution, competent and comprehensive approach by multidisciplinary specialists and establishment of the evidence-based and objective minimum subsistence level in the Republic of Kazakhstan.

One of the ways to solve a given problem, we believe, could be the introduction of a category of the minimum consumer budget along with the concept of a living wage. "If the cost of living is determined, first of all, by human physiological needs, the minimum consumer budget is aimed at meeting the social needs of the person, so its size is several times higher than the subsistence level. This indicator should be the benchmark for determining minimum wages, pensions, scholarships and other social benefits. Consumer basket as the basis of the minimum consumer budget differs from country to country, not only by the methods by which it is calculated, but also in its composition. For example, in the US consumer basket includes 300 items of goods and services, in France - 250, in the UK - 350, Germany - 475" (Babaev, 2009, pp. 20-21).

Legislative provision of the poverty line value in the RK is ensured by the Law "On subsistence minimum" that is set depending on the economic possibilities of the state and serves as a criterion for social assistance to the citizens in need. The value of the poverty line is determined quarterly on a basis of a percentage of the subsistence level by the Ministry of Health and Social Development of the Republic of Kazakhstan. The social significance of the poverty line is to grant the right of people whose income is below a given parameter, qualify for social aid in the form of cash payments at the expense of local budgets.

Thus, the volume of the poverty line is defined by the Ministry itself, arbitrarily, without appropriate legal and scientific reasoning. This function of the central authorized body has been criticized by the deputies of the Parliament of Kazakhstan (Poverty line, 2003). In particular, the Prime Minister of Kazakhstan was sent a request on behalf of 52 deputies of the Majilis Parliament, stating: "The criterion for targeted social assistance to low-income citizens is the poverty line. However, the definition of the poverty line in the methodical plan has no clear criteria: in accordance with the Law "On subsistence minimum", the poverty line is set "in the country depending on the economic opportunities" and determined "on a quarterly basis in the republic, as well as at the regional level". At the same time, the Law "On subsistence minimum" states: "Poverty line - the boundary of the income necessary to meet the minimum needs of the person". But in fact it is the same as the definition of "subsistence minimum" in the rules of the same Act: "subsistence minimum - the required minimum cash income per person equal in value to the minimum consumer basket".

The only difference is that, in accordance with the Law "On subsistence minimum", the value of subsistence minimum is calculated, and the value of the poverty line is set. The value of the subsistence level calculated by the method of (correctly or not - is another question, in our opinion, it is incorrect to the extent that understated the minimum 
required expenditure on non-food goods and services), and the poverty line is set arbitrarily. Moreover, the criteria for the limits of arbitrariness are none neither in the Law "On subsistence minimum", nor in the decision of the Government of the Republic of Kazakhstan "On the procedure for determining the poverty line" (№ 537 dated April 8, 2000), nor in the rules for determining the poverty line, approved by the Government of the Republic of Kazakhstan in April 8, 2000 № 537.

This legal uncertainty of the "poverty line" has meant it is defined (by the Ministry of Health and Social Development of the Republic of Kazakhstan for the republic and the competent authorities of Labor and Social Protection of the regions and cities of Astana and Almaty for the regions) using the parameters of income, insufficient of even to pay the minimum food basket (calculated "on scientifically sound physiological norms of food consumption"). This can be stated as violation of para. 1, Art. 1 of the Constitution of the RK, which established that the highest values of the Republic of Kazakhstan are the man, his life and the law". It should be emphasized that, to date, this problem has not found its adequate resolution, since in Kazakhstan's legislation there is no reasonable mechanisms and parameters determining the poverty line.

The concepts of "poverty" and "subsistence minimum" have to be adjusted in accordance with international standards in terms of compliance in terms of money given two values. Of course, the category of "poverty" and "subsistence minimum" have a different meaning and social significance. However, according to the Law of the Republic of Kazakhstan dated by November 16, 1999 № 474-I "On subsistence minimum": poverty line is the boundary of the income necessary to meet the minimum needs of the person that is installed in the country depending on the economic opportunities. In view, paragraph 1 of Article 1 of the normative legal act states: subsistence minimum is the required minimum cash income per person equal in value to the value of the minimum consumer basket. Naturally, the satisfaction (in monetary terms) of the minimum human needs, that is, the poverty line, must comply with the minimum consumer basket, i.e. the cost of living, income below the consumer basket does not provide a very physical existence of man, and cannot provide the vital functions.

Studies on the phenomenon of "poverty" state that understanding of poverty in terms of income is the most narrow understanding of poverty. A person is considered poor if its income level is below a certain level. Many countries determined the level of extreme poverty by the level of income required to purchase a certain (minimum) amount of food (minimum food basket).

Nowadays, there are two widespread concepts of assessing poverty in terms of income - absolute and relative. The absolute concept of poverty suggests the cost of living as criterion of poverty, including the cost of the minimum food basket, as well as the cost of essential services and non-food items. Comparison of subsistence minimum with the cash income or consumption of the population enables to determine the proportion of the poor. The United States is one of the few major countries in which the official poverty line is set, designed and officially approved in the 1960s. Absolute poverty line is defined on the basis of the minimum requirements for food products. According to experts, food accounts for one third of the totality of the most important consumer products. In determining the value of the poverty line and amount needed to buy food, is tripled. Persons are categorized as poor based on income before taxes. Thus, in the US the cost of living is calculated as three times the cost of the minimum food basket. According to the 1998, the subsistence level (i.e. the poverty line) in the United States amounted to 11.41 dollars a day, and the official poverty level $-12.7 \%$. For cross-country comparable estimates of absolute poverty in developed countries, the World Bank used the absolute poverty line, which is equal to 14.4 US dollar per day in purchasing power parity (PPP) of the national currency, and 4.3 USD in PPP for the countries with economies in transition since 1996.

According to the World Human Development Report 2000, UNDP, the level of absolute poverty in the UK was $13.1 \%$, Germany $-11.5 \%$, USA - 14.1\%, France - 12.0\%. In transition countries, poverty is wider. In Russia, 50\% of the population have a cash income not exceeding 4.3 USD in PPP per day, in a number of other CIS countries the percentage is even higher, reaching $84 \%$ in Kyrgyzstan. The calculation is generally based on cash income of the population. It should be noted that countries with economies in transition, a comparison of cash income to the subsistence minimum overestimates poverty, because there are hidden income, as well as products grown on private farmsteads and natural transfers play an important role. Therefore, in many countries the basis of actual consumption the total revenue is calculated, including the hidden income, the cost of produced and consumed the household products and in-kind transfers.

In the relative concept of poverty, incomes compared with the average wealth achieved in a given society. The relative poverty line is set at a fixed percentage of median household income. EU countries use relative poverty and determine poor people as those having less than $50 \%$ of the median equalized net income (as alternatives can be taken $40 \%$ or $60 \%)$. The problem of this approach is that the number of persons defined as poor, which may have little to do with the number of persons living in real poverty, may increase or decline simply due to changes in median income and its distribution. According to the World Report on Human Development 2000, UNDP, the level of relative poverty in the 
UK was 10.6\%, Germany - 5.9\%, Italy - 12.8\%, Canada - 10.6\%, USA - 17.3\% France - 8.4\%, Japan - 11.8\%.

Poverty in terms of basic needs is in turn a broader understanding of the problem of poverty. Poverty is understood as the deprivation of material preconditions necessary to meet the minimum acceptable requirements, including the need for food. This concept is based not on the level of income that allow these needs, but of the opportunities offered by the society to prevent people from slipping into poverty.

The concept of basic needs, which appeared in the 1960s in the research community in Scandinavia, in 1976, fell as the basis of the report of the International Labor Organization (ILO) "Employment, growth and basic needs". The essence of this concept is that it invites governments to build economic and social policies based on: a) the satisfaction of certain mandatory minimum family needs for food, clothing, housing and household goods; b) improvement of public services in the field of drinking water, sanitary conditions of places of residence, public transport, health and education. International Labor Organization, followed by other organizations within the UN system, align these needs with human rights and believes it is important for achieving the concept of "basic needs", emancipation peoples' initiatives, involving them in "development through participation" at the level of decision solutions, and at the level of practical embodiment.

According to Article 25 of the Universal Declaration of Human Rights, everyone has the right to a standard of living, including food, clothing, housing and medical care and necessary social services, adequate for the health and well-being of an individual and of his family, the right to security in the event of unemployment, sickness, disability, widowhood, old age or other lack of livelihood in circumstances beyond person's control (Shokamanov, 2012). Thus, international standards for social and labor not only expand the content of the subsistence level, but their implementation is associated with the creation of states guarantees in the realization of social rights to an adequate level. The level in terms of basic human needs and quality of life in the event of disability due to social benefits, and when entering into an employment relationship - at the expense of wages. International social standards require states to address poverty in terms of income at or below subsistence level, and involves the provision of guaranteed by the state social support in a given situation. Tuinov (1999) makes a fair conclusion in this regard that the state is obliged to implement international obligations concerning all human rights and fundamental freedoms, including socio-economic rights, regardless of their level of economic development of the state.

In the Republic of Kazakhstan in accordance with the Basic Law of the country adopted the policy of building a legal, democratic and social state. It should be emphasized that the "democratic constitutional social state is a pattern in the natural-historical development of society. At a certain stage of development, the society sets as a goal to the formation of a democratic legal institutions of the social state" (Oseychuk, 2009, p. 25). In accordance with this basic development target of the state during the period of construction of market relations in the years of sustained economic growth in the current financial and economic global crisis, social priorities remain indisputable for state authorities. The indicators of minimum social standards for pensions and guaranteed wage, including in terms of the global financial crisis, most vividly show and reveal the principled position of Kazakhstan on the construction of the social state.

Appeal to the indicators of social development at the expense of the republican budget for 2014 shows an increase in government spending in this area, the expansion of the forms of state aid over the previous calendar year. It should be noted that this trend is the strategic direction of the Republic of Kazakhstan in the social and labor sphere, which is aged for many years. It is especially important to emphasize this fact, not only in terms of sustainable economic growth, but also in terms of financial and economic crisis phenomena (Khamzin and Khamzina, 2009).

\section{Calculation of the Minimum Subsistence Level in the Republic of Kazakhstan}

The phenomenon of poverty is associated with complex social relations that arise between state and society. Systemic poverty reduction provided by the interdisciplinary nature of the legal regulation, interdisciplinary approach to the problem. Since the introduction of the "poverty line" category in the Republic of Kazakhstan in the beginning of 2000, its content has not been changed. As in the Soviet period, it is based on the concept of absolute poverty, that is equivalent to the cost of the minimum consumer basket. In Kazakhstan, the absolute concept is being applied, originating from the establishment of the poverty line by forming the minimum consumer basket. The unit of this poverty concept is applied to all social programs provided by the legislation and financed from the state budget. Basis for poverty monitoring statistics are sample survey of households. The household is an economic entity consisting of one or more individuals living together, uniting their income and property, and consume goods and services in whole or in part. For comparison with the poverty line, the indicators of revenues, expenditures and available resources are used.

In accordance with the legislation of the Republic of Kazakhstan, the subsistence minimum is calculated by the state authorized body on the basis of the cost of the minimum food basket increased by a fixed share of the costs to the minimum necessary non-food goods and services. The subsistence level is calculated quarterly on the national and 
regional on average: per capita; by sex and age groups. Minimum consumer basket is the minimum set of food, goods and services needed to ensure human life, in volume and value terms. Consumer basket consists of food basket; fixed share of the costs of non-food goods and services. The food basket is calculated by the authorized body in the field of state statistics on scientifically sound physiological norms of food consumption approved by the competent authority in the field of health and disease in coordination with the competent authority in the field of health.

The subsistence level is intended for annual: assessment of living standards and to determine the poverty line; identify areas of social policy and the implementation of measures of social support of the population; study provides for a minimum monthly wage, minimum pension and basic social benefits.

The poverty line - the border income required to meet the minimum needs of the person that is set in the country depending on the economic opportunities. The poverty line is based on the subsistence level. It is calculated on a quarterly basis in the republic, as well as at the regional level in the order established by the government of the RK. The poverty line is the criterion for social assistance to needy citizens. In Kazakhstan, the national poverty line is mainly used for targeted social assistance in order to identify those who are eligible for such support. With regard to the basic forms of social security (e.g. minimum pensions, benefits and other social payments), their size is determined on the basis of the subsistence level, some form of social security paid in cash below the subsistence level.

From 2000 to 2006, the poverty line was 30\% of the subsistence minimum, in 2006, it was increased by $10 \%$ per cent, but the increase in the number of poor in Kazakhstan during this period did not happen because the specified time interval associated with the rapid growth of income of the general population in the RK.

\section{Discussion and Conclusion}

The methods of defining poverty used in the RK was adopted from the Soviet period, and does not meet modern demands of society and the social organization of the state. The poverty line and the subsistence minimum does not correspond to universal international standards. We believe that one of the main directions in the development of social and labor relations should be the introduction of international standards for social and labor rights in the RK. This issue requires comprehensive analytical work on the systematization and analysis of the existing domestic legislation for compliance: firstly, with the international standards of social and labor rights; secondly, content and material terms of volume and amount of forms of social protection and the relevant requirements of generally recognized standards.

This direction of improving the legislative process, in our opinion, will have a positive impact on the performance of the RK to their international social commitments, will enable to raise the qualitative efficiency for implementing and applying international norms. Scientific forecasting of the consequences of adopting regulations in the social and labor sphere in terms of social, economic, political and other aspects is mandatory. The implementation of domestic law on international social and labor standards in respect of which the RK has expressed its agreement, and the result of this activity needs a qualitative study. An effective, satisfying the requirements of generally accepted norms of international, social and labor law of the RK should be created. The improvement of the methodology for determining the subsistence level, the implementation of its calculation based on zoning of the country on the living conditions of the population as well as recalculation of the consumer basket based on the actual needs of the population is required.

Amount of targeted social assistance is seen necessary to appoint in proportion to the subsistence level of the respective administrative-territorial unit, but not less than the law on the national budget for the calendar period. To date, assistance is assigned as the difference between per capita income and installed poverty line in the area (city of republican status, capital) based on each family member. The size of the poverty line is determined on a quarterly basis as a percentage of the subsistence minimum, depending on the economic opportunities. To date, it is no more than 40 percent of the subsistence minimum. Thus, the amount of granted aid is the difference between 40 percent of the subsistence level and the actual income of the person (family), which is unacceptable from the point of view of generally accepted social standards. In essence, the state provides assistance to the poorest families only at the level of $40 \%$ of the subsistence minimum. We believe that aid in monetary terms should match the level of the subsistence minimum established in the respective administrative-territorial unit and not be lower than the national importance.

It is required to bring the law guaranteed the minimum wage to a higher social indicator - the minimum consumer budget, and the poverty line is to be defined at the level of the subsistence minimum.

The concept, which is applied in the Republic of Kazakhstan for the calculation of poverty, is not sufficiently objective, because it is erroneous to consider as poor only those whose income is below the subsistence minimum. The subsistence minimum in Kazakhstan, despite its systematic increase, is still very low and it is problematic to live a month on that amount. Therefore, it is necessary to objectively assess the situation and consider as poor not only those who earn less than the minimum subsistence level, but also those who cannot afford a decent life due to lack of livelihood. 
The poverty rate in Kazakhstan is still at a very high level, and due to the economic crisis, this level will continue to rise.

Overcoming poverty must be a priority of the government in the coming period.

\section{References}

Atkinson, A. (2004). Poverty. In J. Eatwell, M. Milgeyta, \& P. Newman (eds.) Economic Theory (pp. 688 -701). Moscow: INFRA-M.

Babaev, L.Y. (2009). Poverty and social policy in the Republic of Tajikistan. Author. dis. ... Doctor of Philosophy sciences, Dushanbe.

Clark, D.A. (2005). The Capability Approach: Its Development, Critiques and Recent Advances. Global Poverty Research Group. [Online] Available: http://www.gprg.org/pubs/workingpapers/pdfs/gprgwps032.pdf (March 19, 2015).

Clark, D.A., \& Hulme, D. (2005). Towards a Unified Framework for Understanding the Depth, Breadth and Duration of Poverty. Global Poverty Research Group, Institute for Development Policy and Management University of Manchester, UK. [Online] Available: http://www.gprg.org/pubs/workingpapers/pdfs/gprgwps020.pdf (March 19, 2015).

Khamzin, A.S., \& Khamzina, Z.A. (2009). Problems of activity of the state to ensure social rights in Kazakhstan: the constitutional and legal research. Astana.

Maleva, T.M., \& Ovcharova, L.N. (2010). Social support: lessons from the crisis and vectors modernization. Moscow.

Oseychuk, V.I. (2009). Constitutional and legal problems in the construction of a democratic legal Russian welfare state. Author. dis. ... Doctor of law sciences, Tyumen.

Poverty line (2003). Online Newspaper "ZONAkz". [Online] Available: http://www.zonakz.net/articles/2940 (February 20, 2015).

Razumov, A., \& Yagodkina, M.A. (2007). Poverty in modern Russia. Moscow: The formula right.

Schumpeter, J. (2011). Chapter 4. Alfred Marshall (1842-1924). In Ten Great Economists: From Marx to Keynes (pp. 138-161). Moscow.

Sen, A. (2004). Development as Freedom. Moscow: New Publishing House.

Shokamanov, J.K. (2012). Analysis of Poverty in Kazakhstan: global problems, national and regional peculiarities. Newsletter number 4: The problem of poverty in the context of social policy in the Republic of Kazakhstan. [Online] Available: http://www.undp.kz/ projects/files/118-30507.htm (February 20, 2015).

Townsend, P. (1988) Deprivation. Journal of Social Policy, 16 (2), 125 - 146.

Tuinov, O.I. (1999). International humanitarian law: textbook for high schools. Moscow: Publishing Group NORMA - INFRA. 